\title{
The Effeminized Hero or Authorial Projection: Charlotte Bronte's The Professor
}

\author{
Mahameed Mohammed ${ }^{1}$ \\ ${ }^{1}$ Department of English, Faculty of Arts and Sciences, Middle East University, Amman, Jordan \\ Correspondence: Mahameed Mohammed, Department of English, Faculty of Arts and Sciences, Middle East \\ University, Amman, Jordan. E-mail: mmahameed67@yahoo.com
}

Received: January 10, 2018 Accepted: February 24, 2018 Online Published: February 26, 2018

doi:10.5539/ells.v8n1p120 URL: https://doi.org/10.5539/ells.v8n1p120

\begin{abstract}
Charlotte Bronte in most of her novels, as suggested by Gilbert and Guber, in The Mad Woman in the Attic (1979), has worked out a vision of an indeterminate, usually female figure (who has often come "from the kitchen or some such place") trapped — even buried — in the architecture of a patriarchal society and imagining, dreaming or actually devising escape routes, roads past walls, lawns, antlers, to the glittering world outside. Like Charlotte Bronte, many nineteenth century women almost wrote in "a state of "trance", about their feelings of enclosure in "feminine" roles and patriarchal households. And wrote, too, about their passionate desire to flee such roles or houses" (313).
\end{abstract}

Keywords: Bronte, The Professor, women, feminine, hero

The Professor (1856), Bronte's first novel, based on her Brussels experience, is the story of the professional and personal fortunes of William Crimsworth the central character, as narrated by himself in first person. The Professor opens featuring "a copy of a letter sent... a year since" by the novel's first person narrator and protagonist, William Crimsworth to Charles, "an old school acquaintance" of his at Eton. The letter is designed to furnish Charles with a detailed account of the course of events that took place after his leaving Eton. The letter doesn't reach Charles, the desired recipient, as he has already left on government appointment to some colony, and the purpose of the letter remains unrealized. William then starts up once again from where he left out in the letter to regale "the public at large," furnishing them with a detailed account of his industrious life in the autobiographical novel form, originally begun only for "the private benefit" (15). The story proper begins with his movement from Eton (South of England) to the north of England where he goes to stay with his entrepreneur elder brother, Edward, who joins him as second clerk managing the foreign correspondence of the House. The extremely dull task of copying and translating business letters and the pointedly rude, even hostile antipathy of his employer brother, make him feel victimized and "Crimsworth invoking his translator's prerogative converts his linguistic mobility into geographic form" (Plasa, 56) and makes a journey to Belgium. The second section of the novel comprises his experiences in Brussels as an English teacher teaching male and female pupils in schools run by Monsieur Pelet and Zoraide Reuter, respectively. This section forms the major part of the novel, picturing William's mental and emotional growth along with his financial independence, secured through fate, industry and endeavour. In the final stage of the novel, we see Crimsworth returning to England with his Anglo-Swiss wife, his former pupil Frances Evans Henri, and their refractory young son Victor to lead a comfortable retired life, made possible through having worked hard, lived frugally and having saved enough money during their stay at Brussels; the deprived, desolate, slavish William (the male Charlotte Bronte as he is called), is transformed into a masterly professor.

In The Professor, a pseudo-masculine Bildungsroman, Bronte chooses a male narrator for the sake of apparent objectivity but Winifred Gerin (1959) considers it an intrinsic demerit in her work. By attempting this kind of a male impersonation, Gilbert and Gubcr feel that the novel nevertheless explores the problem of the literally and figuratively disinherited female in a patriarchal society and attempts (though not quite successfully) to resolve "the anger and anxiety of its author both by examining her situation through sympathetic male eyes and by transforming her into a patriarchal male professor, an orphaned underling turned master" (317). Along with his conventional masculine qualities, Crimsworth is endowed with several stereotypical female qualities rendering 
him curiously androgynous. He is "wrecked and stranded on the shores of commerce" (Chap 4). Thus, disinherited and orphaned, he is like women in a male society, powerless and subordinate, repressed, economically dependent, and almost non-existent, like Charlotte Bronte felt herself when her own early attempts at financial independence failed. But as a male, William Crimsworth executes an exemplary progress from powerlessness to mastery.

Inga Stina Ewbank in Their Proper Sphere: A Study of The Bronte Sisters as Early Victorian Female Novelists (1966) observes that The Professor shows Charlotte Bronte caught in a dilemma of being too anxious to draw on her own experience and at the same time too anxious to objectify. Her first novel is an example of truth to life gained deliberately at the expense of imaginative truth (192-193). The Professor is the story of William Crimsworth's struggle up the "Hill of Difficulty", his struggle for economic independence and a fulfilled emotional life. This prosaic representation of the life of her hero seems strange to the readers of her Angrian stories abounding in imaginary, flamboyant characters accepting superhuman challenges, performing exemplary and exotic deeds. Elizabeth Gaskell also describes The Professor as a "reaction against the exaggerated idealism of Bronte's early girlhood." in (Stone, 1980, p. 110). Phyllis Bentley (1969) in Bronte's and Their World also expresses a similar opinion:

The Professor is, so to speak, a mirror-image of' (Charlotte's own) Brussels experiences: An English teacher in a Brussels school notices, admires and last loves the shy little Anglo-Swiss pupil teacher. In the preface, which Charlotte later wrote, for this, her first novel of real life she tells how she got over any taste for ornamental and redundant composition and had to prefer what was plain and homely (93).

In the Preface to the novel, Charlotte writes:

my hero should work his way through life as I had seen real living men work theirs-that he should never get a shilling he had not earned-that no sudden turns should lift him in a moment to wealth and high station; that whatever small competency he might gain, should be won by the sweat of his brow; that, before he could find so much as an arbor to sit down in, he should master at least half the ascent of the "Hill of Difficulty"; that he should not even marry a beautiful girl or a lady of rank. As Adam's son he should share Adam's doom, and drain throughout life a mixed and moderate cup of enjoyment.

Mrs. Gaskell says, "She went to the extreme of reality, depicting characters as they had shown themselves to her in actual life". And in a letter to Lewis, Charlotte herself confessed:

When I first began to write, so impressed was I with the truth of the principles you advocate, that I determined to take Nature and Truth as my sole guides, and to follow their very footprints; I restrained imagination, eschewed romance, repressed excitement, over bright coloring, too, I avoided and sought to produce something which would be soft, grave and true (Gaskell, 1997, p. 232).

The novel's prospective "publishers, in general, scarcely approved this system" of deliberately eschewing and deprecating her former taste for "the ornamental and redundant in composition" in preference to the "plain and homely" as the Preface suggests, "would have liked something more imaginative and poetical" than the worldly tale of self-advancement she narrates, overturning gender stereotypes in the deceptiveness of appearances, herself concealing behind the masculine mask of Currer Bell as well as William Crimsworth. For the publishers, in her later novels, she had to modify her virtuous course, abandoning the mere transcript of experience and adopting the imaginative process.

Penny Boumelha (1990) in her work on Charlotte Bronte contends, [The Professor's is a world of double ness, where virtually every major character is radically divided; William himself hears two voices within (him) (38). The very title of the novel appears to be a misnomer, signaling a kind of dullness as the meaning of the word is disclosed to Crashworthy by Mr. Brown, "Professor here in Belgium, means a teacher-that is all" (58).]

Boumelha considers it an accurate designation for Crashworthy as he, like several of the other key figures in the text is precisely a "professor" in the alternative, or non-professional sense repeatedly "manifesting one motive, feeling or state of mind but also privately harboring another" (38).

Many do not approve of Bronte's use of the opening letter, and they consider this epistolary manoeuvre as both a very artificial and clumsy way of presenting the background information which could have been easily incorporated in the ensuing chapters. Brammer (1960) finds the letter an evasion, showing her reluctance to address an unknown public, a falling back on an old and safe mode of novel-writing (50). But knowing who Crimsworth has been modeled after it becomes acceptable.

William Crimsworth is the product of a marriage that crosses class boundaries, his mother coming from an 
aristocratic descent, with "a rare class of face" (15). She mortally offends her aristocratic brothers in her union with his father, the "shire manufacturer", who turns bankrupt a short time before his death: some six months after which his mother dies leaving him and his elder brother Edward in the custody of his affluent maternal uncles. The Brontes, it is said, were also so deprived of their father's companionship that they felt themselves orphaned of both parents (Charlotte's protagonists are all orphans). The tie between father and daughter was such a close and sacred one that they dare not touch upon it in their fiction (excepting for Mr. Home-Paulina relationship in Villette). The reverential tie finds reflection in William's expression: My father was but a name to me, yet that name I did not like to hear mentioned with a sneer to my very face. I answered then, with haste and warmth, "I cannot do better than follow in my father's steps; yes, I will be a tradesman." (8). Without giving a second thought to this impetuously reached decision, the inexperienced, unscrupulous but determined William, in resolute defiance to the sarcastically contemptuous remarks made by his uncles against his father and his trade, rejects their patronage, plunges himself in a "totally untried quagmire" and joins Edward, his elder brother, who is "fast making a future" (9) in the realm of mercantile capitalism as "second clerk". But very shortly after joining Edward, William is full of regrets for the unpromising position to which he is reduced to by his despotic brother and that sets him ponder quizzically over his uncertain prospects "fiercely demanding of my soul an answer": "Why did I make myself a tradesman? Why did I enter Hansden's house this evening? Why, at dawn tomorrow, must I repair to Crimsworth's will? .... I got no sleep, my head burned, my feet froze; at last the factory bell rang, and I sprang from my bed with other slaves" (38).

The ringing factory (bells) seems to prompt a cross-racial identification of William with the slave, summoning the enslaved worker to his duties, participating in the routine factory labor. The bell act as a constant reminder to William of his subservient position and finally climaxing in his rebellious outburst against the tyrant elder brother in a novel to liberate himself from his oppressive "Yoke".

Come, Edward Crinmsworth, enough of this. It is time you and I wound up accounts. I have now given your service three month's trial and I find it the most nauseous slavery under the sun. Seek another clerk-I stay no longer. What do you dare to me notice? Stop at least for your wages. (Edward) He took down the heavy gig-whip hanging beside his Mackintosh (41).

Crimsworth's rebellion against Edward, the despot with a lashing whip in hand, is a master-slave picture, a trope of class in terms of race, the domestic in terms of the colonial. Several critics argue that it is the regulated bodies of the slaves who derive the capitalist economy from which Crimsworth freely withdraws his labor. Crimsworth creates a metaphorical colonization through his identification with the figure of the slave and expropriation of the racial other for his own self-serving ends. The Professor, when placed and considered alongside Douglass's Frederick (1977) text, one of the formative work; in the African American autobiographical tradition, and centrally concerned like The Professor, with processes of self-making, explicitly displays several resemblances. William Douglass emerges triumphed, his "sense of manhood" both "revived" and transfigured in a "glorious resurrection from the tomb of slavery, to the heaven of freedom", and declares like him, "you have seen how a mail was made a slave; you shall see how slave was made a man". However using Macaulay's phrase, Crimsworth enjoys the "aristocracy of skin", a privileged place in comparison to his African American counterpart and his freedom from his brother's shackles seems far easier (Douglass, 5).

The bright hearth fire and the candles burning on the table in the library symbolize and evoke William's desperate craving hope for and an eager expectancy of some intimately extended warm, helping hand and a loving union with his elder brother, Edward, whom he is to meet after a lapse of some ten years. The eager nervousness of the lonely orphan, William, deprived of all relations from birth can be easily read in his own account of the occasion, "Still, as 1 sat awaiting his arrival, I felt eager-very eager-I cannot tell you why; my hand so utterly a stranger to the grasp of a kindred hand, clenched itself to repress the tremor with which impatience would fain have shaken it" (11). Though he anticipates no overflowing of fraternal tenderness as "Edward's letters had always been such as to prevent the engendering or harboring of delusion of this sort" (11). But Edward reflects no gesture of warmth or friendliness, no feelings of kindliness and hospitality expected of him towards a brother who he is meeting after a lapse of ten long years. Instead he shows a cold, stern attitude. One again the feminist subversion and neglect in patriarchy is extended to the relation between the two brothers.

However, William also from the very beginning, is not in a mood to accept servile subordination and subjugation at the hands of his employer-brother and in an exceedingly independent stance reflects "I felt an inward satisfaction that I hadn't in a first moment of meeting, betrayed my warmth, my enthusiasm, that I had saluted this man with a quiet and steady phlegm." (12). A perfect business like a practical deal ensues between the two brothers, suiting William's temperament as well, with William expecting no undue advantageous favor from Edward "on plea of being (his) brother" and Edward authorized "to have the full value of [his] money out of 
[William]". Charles Burkhart (1973) considers William Crimsworth the typical Brontean protagonist in his needs, of finding a place for himself in life and someone to love; in his attitudes-for example, his militant Protestantism; in his personality which has something of the mere looker-on at life, the reticence of Lucy Snow and something of the truculent self-esteem of Jane Eyre (48). Edward, having grown up in painful deprivation of love and care, money and education, develops a malignant resentment for his brother's superior education and derives a kind of malicious pleasure by treating William as an underling. For William, the mill becomes an image of enclosure where "you cannot dream, you cannot speculate and theorize-there you shall out and work!"

(16) William recalls his position in his brother's mill as a subject under surveillance:

I served Edward as his second clerk faithfully, punctually, diligently. What was given to nle to do, I had the power and determination to do well. Mr. Crashworthy watched sharply for defects, but found none, laid Set Flinty Set-to, his favorite and headman to watch also. He was baffled, I was as exact as it, and quicker. Mr. Crashworthy made inquires as to how I lived, whether I got into debt-no, ... as it had ever been abhorrent to any nature to ask pecuniary assistance, I had early acquired habits of self-denying economy; husbanding my monthly allowance with anxious care (22).

Carl Plasa (2015), commenting on William's thrifty frugality, says All the values which define a bourgeois masculinity are operating here, "faithfully punctually, diligently" present and correct from "industry and perseverance." In Heather Glen's (1947) taxonomy, to "self-reliance and independence, self-respect and selfcontrol". By internalizing these values, Crimsworth necessarily leaves Edward and his "head-man" "baffled" and in a true Foucauldian fashion, he subjects himself to the very strategies of surveillance deployed against him (65). He further reads the "accumulated savings", "habits of self-denying economy". and "husbanding" of his "monthly allowance" as a reference to his talents of financial self-management as well as sexual self-restraint and self-discipline.

As William's conscientious earning of his wages gives Edward no chance to find fault with him, the proud, harsh taskmaster grows all the more unjust and at the birthday party where he invites William, he introduces him to no one, rendering him to a very humiliating state as he tells his readers, "I looked weary, solitary and kept down like some desolate tutor or governess" (24). This somehow satisfies and pleases the jealous brother turned taskmaster. Bronte, herself, is called a difficult governess, constrained, melancholic, uncomfortable, and perpetually on the defensive as Margaret Lane quotes her, "I am miserable when I allow myself to dwell on your necessity of spending my life as governess" (129). Craik (1969) observes about Edward:

He is Charlotte Bronte's first working of the dangerous minor character, which looks forward in violence to Mrs. Reed in Jane Eyre and, to a lesser degree, in his uncongenial authority, to Mr. Helstone in Shirley. Like Mrs. Reed he is a force that the hero must overdo as a stage in his own moral growth, though of course, Crimsworth's victory as a grown man is slight compared with Jane's rendering Edward Crimsworth's violent language and his brother's equally violent though briefer replies much less frightening than lane's violence, and Mrs. Reed's dangerous restraint or cowed silence (65).

Gilbert and Guber see Edward's pretty tyrannies as prefiguring the vicious oppressions of John Reed in Jane Eyre. He beats his horse, enslaves his subordinates, and comments Yorke Hunsden "Will some lay be a tyrant to his wife." Commenting on this inexplicably hostile mad despotic, bad-tempered captain of Industry, they say:

And yet, though he is the epitome of patriarchal injustice - the domineering older brother, master of Crimsworth Hall and rightful heir of the maternal portrait that William really loves-Edward has a tyrannical vigor which, Bronte shows, is inevitably rewarded, in a society dominated by equally chastely men: even after his business, he has failed and alienated his rich wife with the batings Yorke Hunsden predicted, he ends up getting richer than Coes'us by railway speculations.

To rebel against the oppressor brother becomes the need of the hour for William. He knows that not to rebel is to be complicit and to be complicit is to be responsible for one's own suffering. In Hansden's words, "When a man endures patiently what ought to be unendurable, he is a fossil." (35) His own submissiveness renders the oppressor all the more arrogantly overbearing. The best way to unburden oneself is to shun all this as William does when he walks out of the counting house, to enter it no more (43).

Like all Bronte protagonists, William also feels like a free, independent, liberated soul, relieved of all sub-servant bondage, the tyrannous yoke removed, he exclaims, "I leave a prison, I leave a tyrant", as he feels "light and liberated" a load being "lifted off my heart" (43). As a liberated bird, freed from its cage, released from all bondage and at liberty to stride to unlimited heights, William embarks for Brussels. For the first time, he experiences the embrace of a supportive maiden, "Liberty", reviving life and hope in him. His enlivening experience reads, "Yes, at the epoch I felt like a morning traveler who doubts not that from the hill he is 
ascending he shall behold a glorious sunrise; what if the track be strait, steep, and stony? he sees it not; his eves are fixed on that summit, flushed already, flushed and gilded and having gained it he is certain of the scene beyond" (53).

The Picture (Bronte) draws is not of an innate, assured masculinity, but rather of a social and gender identity created and sustained only through violence: the violence of self-repression and of repudiation of all who might threaten the carefully nurtured illusion of self-control.

The self control that Crimsworth arrogates to himself throughout the novel is simultaneously a mask for and symptom of an inner split. What he claims to have "perceived" in the other as "mere licentiousness" is more properly the projection or exportation of what he represses in himself. William finds something wanting in "the fair page of Mrs. Crimsworth (Edward's wife's) face"; "a kind of lisp" and with "a somewhat infantile expression", her small features, "without the clear, cheering gleam of intellect" leave no impression on him.

Baker (1937) observes, "All Charlotte's male characters are, of course, a woman's men, or women in shape of man; Crimsworth unfortunately is that and nothing more" (33). Probably, Gilbert \& Gubar share his opinion in their reading of Crimsworth's unusual interest in the "unseen paradise" next door: a "Pensionnat de Demoiselles" as "a characteristically female desire to comprehend the mysteries of femaleness" and they read it as "Bronte's own desire to analyze the walled garden of femininity" (321). Whereas others call it William's sexual awakening when he remarks finding one of the windows in his apartment in the Pensionnat Pellet boarded up. "I thought it would have been so pleasant to have looked out upon a garden planted with flower, and trees, so amusing to have watched the demonic (less at their play: to have studied female character in a variety of phases, myself the while sheltered from view by a modest muslin curtain $[\mathrm{He}]$... is astonished at his flared up desire to peep into the forbidden area and at the amount of disappointment he feels when not able to do so and looks with more "dissatisfied eyes on the most tantalizing board, longing to tear it away and get a glimpse of the green region which I imagined to lie beyond" (63).

To quote Penny Boumelha again, William who initially seeks a "Promethean spark" of intellectual sympathy in woman later acts out in an entirely different relation to it.

Terry Eagleton, in Myths of Power, commenting on the relation of Frances to William, puts it as "transparently sadomasochistic" (42). Frances, "however sad or harassed", voluntarily submits to Williams masterful "directions" and "reproofs" and looks revived, refreshed, happy and serene within no time, and William's remark is worth noting, "the reproofs suited her best of all" (170). Critics see her professional freedom and her independence as obtained only by means of personal submission. Boumelha observes: "The striving for independence and equality in the area of work and earning capacity that the novel allows her is set against the delights of willing submission in intimate relationship" (52).

The insistence that women as well as men need fulfillment in work is one of the new elements of reality in Charlotte Bronte's novels.

Miller (2001) in The Bronte Myth comments, Charlotte was not officially a feminist in the modern, political sense and "did not directly engage in the legal struggle for women's rights". Instead, she preferred a more inclusive definition of feminism which could involve "all women who have broken the mold to fulfill their creative intellectual impetus" (162). Miller tends to overlook how the appropriation of the male voice may in a way challenge a tradition of androcentric narrative and Victorian patriarchal hegemony. As Eagleton in Myths of Power (1975) explains, one interpretation of feminism "is not just that women should have equality of power and status with men, it is a questioning of all such power and status. It is not just that the world will be better off with more female participation in it, it is that without the "feminization" of human history, the world is unlikely to survive" (150). Bronte engages this concern by using an intrinsically authoritative male voice to tell a story that is not about a heroine's traditional growth into power, but instead authorises a masculine growth out of power by asserting the need to temper male authority with "feminine" social virtues, usefully defined by Susan Morgan's "gentleness, flexibility, openness to others, friendship, and love" (19). At the same time, however, Bronte describes the practical and psychological obstacles to this "feminization" for men who are subject to ideological constraints, particularly the insistence on sexual difference.

\section{References}

Baker, E. A. (1937). The Brontes-Charlotte. The History of the English Novel, 8, 11-63. London: M. F. \& G. Witherby Ltd.

Bentley, P. (1969). The Brontes and Their World. London: Thames and Hudson.

Boumelha, P. (1990). Charlotte Bronte. Bloomington and Indianapolis: Indiana University press. 
Brammer, M. M. (1960). The Manuscript of The Professor. Review of English Studies, XI(May), 157-170. http://dx.doi.org/10.1093/res/XI.42.157

Brammer, M. M. A. (1958). Critical Study of Charlotte Bronte's The Professor. Master's Thesis, Bedford College, University of London.

Burkhart, C. (1973). Charlotte Bronte: A Psychosexual Study of Her Novels. London: Victor Gollancz Ltd.

Craik, W. A. (1969). The Bronte Novels. London: Methuen \& Co. Ltd.

Douglass, F. (1997). Narrative of the Life of Frederick Douglass. Boston.

Eagleton, T. (1975). Myths of Power: A Marxist Study of the Brontes. New York: Harper and Row.

Ewbank, I. S. (1966). The Proper Sphere: A Study of the Bronte Sisters as Early Victorian Female Novelists. London: Edward Arnold.

Gaskell, E. (1997). The Life of Charlotte Bronte. London: Everyman.

Gerin, W. (1959). Anne Bronte. London, New York, Toronto: Thomas Nelson and Sons.

Gilbert, S., \& Guber, S. (1979). The Madwoman in the Attic: The Woman Writer and the Nineteenth Century Literary Imagination. New Haven and London: Yale University Press.

Glen, H. (1997). Jane Eyre. New Casebooks Series. London: Macmillan.

Miller, L. (2001). The Bronte Myth. London. https://doi.org/10.1038/35102126

Plasa, C. (2015). Charlotte Bronte. New York: Palgrave Macmillan.

Stone, D. D. (1980). The Romantic Impulse in Victorian Fiction. Cambridge: Harvard University Press. https://doi.org/10.4159/harvard.9780674594302

\section{Copyrights}

Copyright for this article is retained by the author(s), with first publication rights granted to the journal.

This is an open-access article distributed under the terms and conditions of the Creative Commons Attribution license (http://creativecommons.org/licenses/by/4.0/). 